\title{
CHOOSING VALUES? WILLIAMS CONTRA NIETZSCHE
}

\author{
By Matthieu Queloz iD
}

\begin{abstract}
Amplifying Bernard Williams' critique of the Nietzschean project of a revaluation of values, this paper mounts a critique of the idea that whether values will help us to live can serve as a criterion for choosing which values to live by. I explore why it might not serve as a criterion and highlight a number of further difficulties faced by the Nietzschean project. I then come to Nietzsche's defence, arguing that if we distinguish valuations from values, there is at least one form of the project which overcomes those difficulties. Finally, however, I show that even on this reading, the project must either fall prey to 'Saint-fust's illusion' or fall back into the problems it was supposed to escape. This highlights important difficulties faced by the Nietzschean project and its descendants while also explaining why Williams, who was so Nietzschean in other respects, remained wary of the revaluation of values as a project.
\end{abstract}

Keywords: Bernard Williams, Saint-Just's illusion, Friedrich Nietzsche, revaluation of values, conceptual ethics, conceptual engineering.

\section{INTRODUGTION}

Which values should we live by? Is there some consideration that can function as a criterion by which to compare the values we have with possible alternatives? Such questions, which have recently moved to the forefront of philosophy again with the rise of conceptual ethics and conceptual engineering, were of course a central concern of Nietzsche's. ${ }^{1}$ Finding that the values of Christian morality tend to stifle human flourishing by uniformly encouraging self-abnegation and asceticism, Nietzsche formulates the project of identifying and cultivating better values to live by, values that would enhance life instead of stifling it. ${ }^{2}$ This is Nietzsche's project of an Umwerthung der Werthe - a phrase

${ }^{1}$ See Cappelen (2018) and the essays collected in Burgess, Cappelen, \& Plunkett (2020). Cappelen \& Plunkett (2020) open the volume with a programmatic quotation from Nietzsche, in which he invites philosophers to be sceptical of all inherited concepts, make new concepts, and persuade in their favour (I967: 220-I).

${ }^{2}$ See Nietzsche (1967: 45-6, 522, 529, 545; r998: Preface, $\S \S 3-6$; 2002: $\left.§ 4\right)$. See also Richardson (2004: 8I-94, I20), Reginster (2006), Gemes \& May (2009) and Leiter (2015).

(C) The Author(s) 2020. Published by Oxford University Press on behalf of The Scots Philosophical Association and the University of St Andrews. All rights reserved. For permissions, please e-mail: journals.permissions@oup.com 
whose meaning ranges from a shift in to a reversal of values, but which is usually translated as the 'revaluation of values'. On the basis of his doctrine that life is fundamentally will to power - in the technical and notably formal sense of a second-order desire to overcome resistance in the pursuit of first-order desires $^{3}$ - Nietzsche suggests that the corrective criterion for determining which values to live by should be whether a set of values 'enhances people's feeling of power, will to power, power itself' (2005b: §2). ${ }^{4}$ As interpreters have pointed out, there are also passages where the relevant criterion is spelled out alternatively in terms of enhancing life, health, or flourishing. ${ }^{5}$ I shall refer to this criterion as the vitality criterion, exploiting that label's useful ambiguity between power, life, health, and flourishing. Once a criterion is at hand, it can be used to identify and adopt better values to live by. Simplifying wildly, I shall refer to this enterprise in what follows as 'the Nietzschean project'. Whatever else Nietzsche may be up to, ${ }^{6}$ this project is clearly a central strand in his thought.

And yet it is a project which Bernard Williams, though a fervent admirer of Nietzsche and a self-proclaimed 'Nietzschean', always remained deeply wary of. $^{7}$ His grounds for doing so are, characteristically, as elusive as they are suggestive. My main concern in this paper will therefore be to elucidate and amplify his worries so as to articulate precisely what Williams' critique is, and what it can teach us about the difficulties faced by the Nietzschean project.

Williams agrees with Nietzsche on three cornerstones of the Nietzschean project: that genealogical inquiry can help us determine whether a set of values has helped us to live; that where our own values are concerned, the verdict will in many respects be negative; and that going forward, the question is whether some other set of values will help us to live (2000: I6o-I). But Williams is adamant that this consideration 'does not function as a criterion' (2000: I6I), and so he resists laying down the fourth cornerstone - the actionguiding criterion - that would be required to support the Nietzschean project of revaluation as an enterprise for practical deliberation.

\footnotetext{
${ }^{3}$ I follow Reginster (2006: II; 2018) in the interpretation of the much-debated notion of the will to power.

${ }^{4}$ The term 'corrective criterion' is Richardson's (2013: $\$ 5$ ). For the claim that life is will to

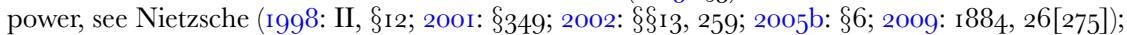
for the claim that the will to power doctrine yields the standard or criterion of revaluation, see Nietzsche (I998: II, §2; 2009: I885, 2[131, I85], I886, 5[71], I887, II [74], I888, I4[136]).

${ }^{5}$ For accounts of the project of revaluation that variously spell out Nietzsche's criterion in terms of life, power, health, or human flourishing, see May (I999), Ridley (2005), Guay (2006), Gemes (2013), Katsafanas (2013a,b), Richardson (2013), Leiter (2015), Clark (2015b) and Merrick (2018). For an account of the criterion as being less about the effects of values than about the ideals they express, see Huddleston $(2015,2019)$.

${ }^{6}$ Another strand is his critique of ascetic conceptions of values, which I have argued elsewhere is logically prior to the revaluation of values; see Queloz \& Cueni (2019).

${ }^{7}$ Pressed by Habermas to say whether he was an Aristotelian or a Wittgensteinian, Williams answered (perhaps not altogether in earnest): 'How about I'm Nietzschean?' (I999a: 246). For explorations of Williams' debts to (or parallels with) Nietzsche, see Clark (20I5b), Katsafanas (20I6), Leiter (manuscript), Prescott-Couch (2014), Queloz \& Cueni (2019), Queloz (2017, forthcoming-a,b: ch. 7), and Robertson \& Owen (2013).
} 
It is not, of course, that Williams takes revaluations of values to be impossible: there clearly can be revaluations, because there obviously have been. ${ }^{8}$ The point is rather that the possibility of a revaluation of values becomes doubtful once that revaluation is conceived as a project rather than as a historical phenomenon. Once conceived as a project, it properly becomes an object of practical deliberation and calls for choices between the values we have and possible alternatives. But unless they are to be arbitrary, these choices will have to be guided by some criterion (even if, as some interpreters of Nietzsche have suggested, that criterion is context-sensitive, personalized, or embodied). ${ }^{9}$ And this is where the Nietzschean project goes wrong on Williams' view:

It is not - and this is vitally important - that an increase in power can serve as a criterion of what interpretation or outlook we should adopt. We do not survey a range of perspectives or sets of values and choose one by considering the extent to which it will increase our power. (2006d: 327)

An 'increase in power, in a sense adequate to Nietzsche's purposes', Williams maintains, could not 'be the criterion of anything' (2006d: 327).

Interestingly, however, Williams' critique of the Nietzschean project does not simply stem from a disagreement over the substance of Nietzsche's criterion. Williams' misgivings are deeper than that, and his critique all the more powerful for being insensitive to what exactly the substance of Nietzsche's criterion is taken to be: he would resist the Nietzschean project on any interpretation of the operative criterion, because he thinks that whether we should move over in the direction of alternative values is, quite simply, 'not a question for deliberation or practical reason' (2000: I6I). It is a question to be answered by life itself, and all we can deliberately do is discover after the fact how it was answered:

It is not a matter of choosing some concept or image on the ground that it will help us to live. It is a matter of whether it will indeed help us to live, and whether it will have done so is something that can only be recognized first in the sense that we are managing to live, and then later at a more reflective level, perhaps with the help of renewed genealogical explanation. (2000: I6I)

The crucial point, then, is that the merits of values as measured by some criterion - not just the extent to which they serve the will to power, but any criterion - can only be assessed retrospectively. The question whether 'some other ways of living, something which includes other ways of thinking about living, will help us, or other human beings who follow us, to live' (2000: I6I), Williams insists, does not function as a criterion.

Somewhat puzzlingly, Williams presents this as 'one of Nietzsche's most important lessons' (2000: I6I). But how can it be Nietzsche's lesson? Is it not

${ }^{8}$ As Nietzsche himself argues (I998: I, $\S \S 7-$ IO; 2002: $\left.\S 46\right)$.

${ }^{9}$ See, e.g., Richardson (2013). 
precisely the point of Nietzsche's project that it takes that question as a criterion and thereby empowers 'free spirits' to liberate themselves from the stifling grip of inherited values and choose a better way to live? And more importantly, why is it that neither an increase in power nor any other way in which values help us to live functions as a criterion by which to choose values? Should it not, or can it not? These are the questions I propose to address in what follows.

\section{WILLIAMS' CRITIQUE OF THE NIETZSCHEAN PROJEGT}

One clue for why the question whether a set of values will help us to live does not function as a criterion lies in Williams' remark that other ways of living include other ways of thinking about living. This means that as we consider possible future values and evaluate them according to our present ways of thinking about living, a different evaluative basis will be nested in the object of our evaluation, and the question arises of which evaluative basis - which standard - is the relevant one. Let us call the evaluation of possible future values by the standard of our present values evaluation from here:

\section{Evaluation from Here:}

At $t_{1}$, I evaluate, according to the vitality criterion as spelled out in terms of my values $V_{\mathrm{t} 1}$, to what extent, at $t_{2}$, a given set of alternative values $V_{\mathrm{t} 2}$ would help me to live.

The other possibility is to consider whether these values will be seen to help us to live at $t_{2}$ given the values we have at $t_{2}$. Let us call this evaluation from there:

\section{Evaluation from There:}

At $t_{1}$, I evaluate, according to the vitality criterion as spelled out in terms of a given set of alternative values $V_{\mathrm{t} 2}$, to what extent, at $t_{2}$, the values $V_{\mathrm{t} 2}$ would help me to live.

The main thrust of Williams' critique of the Nietzschean project is to argue that Evaluation from Here is feasible but not relevant while Evaluation from There is relevant but not feasible. Let us start with the relevance claim: it is a plausible default assumption that what we - as Nietzschean revaluators - would really like to know is how future values shape up from the point of view of those who actually live by them. After all, they are the ones who have to live with those values. But could there not be conditions under which we would have reason to treat Evaluation from Here as the relevant standard? In order to be able to say with confidence that Evaluation from There really is the relevant standard for Nietzschean revaluators, we first need to grasp what conditions, if any, would license privileging present values over future ones.

In 'Persons, Character, and Morality', Williams suggests that in order to be justified in evaluating from here, i.e. in giving my present values authority over the life of my future self with different values, I would need an understanding 
of how those future values relate to my present values, and that understanding would have to be such as to vindicate my privileging my present values over my future values. To illustrate this point, Williams discusses Derek Parfit's example of a Russian nobleman who knows he will inherit vast estates, but whose socialist ideals now make him want to give those estates away when he does so. To guard against a change of heart, the Russian nobleman arranges for the estates to be given away automatically, and makes any revocation conditional on the consent of his wife, whom he asks to disregard any future change of mind on his part. ${ }^{10}$ In this case, Williams argues, it is not clear that the nobleman's present values really have more authority than his future ones, for even if he has some story to tell about why his later values should be discounted, it is not clear why that story should have more authority than the countervailing story that he can expect his later self to tell about his earlier self. As Williams puts it, he may have 'a theory of degeneration of the middle-aged, but then he should reflect that, when middle-aged, he will have a theory of the naiveté of the young' (I98I: Io).

But we can easily think of an example where authority is more clearly on the side of the present. When Odysseus instructs his men to tie him to a mast as they approach the sirens and to disregard whatever orders he may give once they get there, he is privileging his present attitude in light of a theory explaining why his future attitude, under the influence of the sirens, counts for less. He knows he will change his mind and ask to be freed, but he also knows that he will only think that because he will come under the spell of the sirens. This explanation relating his present to his future self vindicates discounting the opinion of his future self.

Accordingly, in order for one's present values to possess enough authority to defeat one's future values, two conditions would have to be fulfilled: first, one would need what might be called a theory of change, a robust understanding of how and why one's future values came to differ from present ones; and secondly, that theory would have to vindicate one's present values against one's future values, thus explaining why these should count for less. This is true not just where the person doing the evaluating and the person being evaluated are the same person - though that case does raise problems of its own having to do with personal identity ${ }^{11}$ - but also at the level of society. The kind of understanding relating successive outlooks to each other is often available when it comes to relating past outlooks to present ones, because we have access to many of the facts explaining how we came to be where we are; but it is not, typically, available when it comes to relating present outlooks to future ones. And absent such an understanding, there is no reason to think that Evaluation from Here possesses more authority than Evaluation from There.

\footnotetext{
${ }^{10}$ See Parfit (1984: 326-7).

${ }^{11}$ See Williams (r973b: 93; r98r: 9-10).
} 
Granted that Evaluation from There is the relevant standard, the issue becomes that of its feasibility. Williams is clearer about the fact that he thinks it unfeasible than about his reasons for thinking this. Two compelling rationales can, however, be reconstructed from his remarks. The first is that the content of future values is likely to be inaccessible to us; and the second is that even if those future values were accessible to us in terms of their content, life with those values would not be recognizable to us as an improvement except insofar as it realized the values we now have.

The problem of the inaccessibility of the content of future values is highlighted by Williams when he writes that in contemplating a set of possible future values we do not yet live by,

we cannot understand in advance what kind of power it will create, what new forms of life it will make possible, or how those forms of life could express human vitality - just as the ancients could not have foreseen the distinctive shape of that world the creation of which [Nietzsche's On the Genealogy of Morality] claims to describe, a world centered on Christianity; nor could they have understood how that utterly strange thing could come to represent a new way of giving life a meaning. (2006d: 328$)$

We may be able vaguely to envision what would be involved in living with a certain set of future values by situating them in a space of human problems or concerns, or by characterizing them in terms of their effects. But this is merely to consider these values from the outside, when what we really need is to understand them from the inside, so that we can see what life looks like from there. From where we are now, we may anticipate the coming of values that are not the ones we presently have, but this is a long way from grasping what it is that one values when one has those values, and why one values it. Insofar as future values involve the introduction of genuinely new concepts that differ both from those we now live by and from those we have inherited, we will not be able to think the ethical thoughts expressible in terms of those concepts (it is partly for this reason, Williams (2006b: 197) suggests, that Marxism and many other ethical and political conceptions culminate in static utopias). Yet thinking the ethical thoughts expressible in terms of the future values at issue is what one certainly must do before the question of one's ability to evaluate from these future values can even arise.

The second problem is that even if those future values were accessible to us in terms of their content, living by those values would not be recognizable to us as a genuine improvement except insofar as it served values we shared already. ${ }^{12}$ What would be recognizable to us is that to them, i.e. to the possible future

\footnotetext{
${ }^{12}$ Thus, when someone in a slave-holding society envisages a possible future society without slavery, the measure of the improvement this would bring is provided by the values the society has already. What is at issue in Williams' critique are even more radical changes recognizable as improvements only as measured by values they themselves instil. I am grateful to a reviewer for pressing me on this point.
} 
agents living by those values, it would be recognizable as an improvement; but that does not make it a genuine improvement in our eyes. For even if we understood that the envisioned life was going better, by the light of some future values, than our life was going according to our values, this would still not amount to an ethical judgement that the envisioned life was simply going better and we should move towards it. From where we are now, any picture of future human life that failed to embody the values we now live by would elicit a sense of loss. As Williams puts it,

we cannot overcome our outlook. If a possible future that figures in those shadowy speculations does not embody some interpretation of [the] central elements of our outlook, then it may make empirical sense to us - we can see how someone could get there - but it makes no ethical sense to us, except as a scene of retrogression, or desolation, or loss. (2006b: 197)

To those future people with different values, it would of course not appear as a scene of retrogression, or desolation, or loss. But the point is that this vicarious judgement is not an ethical judgement in the relevant sense. We cannot, in the relevant sense, try on values for size. What we can do, as Williams himself insisted (I986: 203), is take up the ethnographic stance and imaginatively inhabit an evaluative viewpoint - that of a different contemporary culture, or that of a culture in the past - without fully making it our own. ${ }^{13}$ But even if we had enough of a grip on a future evaluative viewpoint to imaginatively inhabit it, so that we could see how someone inhabiting that viewpoint would evaluate things, this remains crucially different from actually evaluating them. To actually evaluate them is to make sense of them in an ethically engaged way. ${ }^{14}$ This yields judgements of the form: 'Values V help/do not help people to live'. To evaluate them vicariously, by contrast, is to make sense of them in an ethically disengaged way. This yields judgements of the form: 'To people with values $\mathrm{V}$, it looks like these values help/do not help them to live'. But this is not to express or take up an ethical stance towards those values. The force of the two judgements is different - only the judgement expressing values one actually holds is what might be called a full-throated ethical evaluation, while the vicarious judgement is a disengaged evaluation more akin to a proposition of anthropology. Even if future values were accessible to us in terms of their content, therefore, they would still not be accessible to us as a basis of full-throated ethical evaluation. Imaginatively inhabiting a future in which values we do not

\footnotetext{
${ }^{13}$ See also Williams (r995a: 206; r995d: 239; r995e: I85-7; r996: 29; 2006e: 6r).

${ }^{14}$ The engaged/disengaged terminology hails from Moore (2006). A helpful account of the distinctive form of agency involved in aspiring to acquire values one does not yet possess is Callard (2018). More decision-theoretic framings of related problems are discussed in Ullmann-Margalit (2006) and Paul (2014). Eklund (2017) explores how the possibility of alternative normative concepts relates to certain forms of metaethical realism, and in particular whether it is possible for concepts with the same normative role to have different referents - a focus which renders it orthogonal to the Nietzschean concerns at issue here, however.
} 
share are successfully realized does not get us past the fact that insofar as this future fails to realize values we actually have, it can only make ethical sense to us as a scene of retrogression or loss.

The vitality criterion is no help here, because what counts as an expression of vitality - as an increase in people's feeling of power, will to power, or power itself, for example - is similarly sensitive to one's actual outlook. The power that a different way of life will embody 'will not reveal itself as recommending it until it is a power that someone already possesses' (Williams 2006d: 329).

It might be objected that this rather overstates the difference between values we live by and values we do not live by. After all, we seem to manage well enough when it comes to evaluating whether the values of past societies have helped them to live by their own lights as opposed to ours. Some societies were clearly disasters on their own terms, and our ability to understand this becomes important when we seek to explain why some societies decided to move away from slavery or honour killings, for example. Indeed, our capacity for this kind of detached retrospective judgement seems to be presupposed by Williams himself when he grants Nietzsche that genealogical inquiry can reveal to what extent values have proved life-promoting in the past (unless the idea is to assess even values from the distant past only by our present values - an exercise whose result for large swathes of history can only be so indiscriminately negative as to be futile). What is so different about future values?

The answer is that both with regard to the accessibility of future values in terms of their content and with regard to their accessibility as an evaluative basis, there are important asymmetries between the past and the future. One is what we might call the hermeneutic asymmetry: while past societies used to make ethical judgements that we no longer make, we often still take the content of those judgements to be accessible to us, because the terms in which they were articulated have been handed down to us. Ethical outlooks may have been lost, but our picture of a lost ethical outlook is paradigmatically one where the terms in which that outlook was expressed have not been lost. By contrast, future ethical outlooks have yet to arise, but our picture of a future ethical outlook is one where the terms in which that outlook will be expressed have not yet arisen either. As a result, the content of many past outlooks is accessible to us in a way that the content of future outlooks is not. ${ }^{15}$

In addition, Williams suggests that there is also an asymmetry between past and future with regard to the second problem of the inaccessibility of future values as an evaluative basis, an asymmetry which might be labelled the identification asymmetry. We can explore our present values 'on this side, in relation to their past, and explain them', and in contemplating the past, 'we can identify with the process that led to our outlook because we can

\footnotetext{
${ }^{15}$ See Williams (2006a: $\left.174-5\right)$.
} 
identify with its outcome' (2006b: 197). That history presents alternative ways of living merely in terms of a wider 'us', because we have available to us a story detailing how 'they' became 'us'. But with regard to the future, that story has yet to be written. As a result, we find it much harder to identify with 'them' as a future 'us'. This in turn makes it much harder to identify with their future values, since on Williams' account, historical narratives about how a society came by its values enable the society to make sense of its values as its own (2006b: 193-97; 2006d: 328-9). Without this kind of narrative continuity, we cannot identify sufficiently with values other than those we now have to be able to evaluate from them. And the identification asymmetry is that while such narrative continuity often obtains (or is taken to obtain) between the past and the present, it is lacking between the present and the future. This is why Williams writes that 'we cannot in our thought go beyond our outlook into the future and remain identified with the result: that is to say, we cannot overcome our outlook' (2006b: 197).

We thus reach the conclusion that the prospective value of another set of values, to the extent that we even understand it, will have to be judged in terms of its tendency to promote the values we already have, while the respects in which adopting this different outlook promotes values it itself instils will only be recognizable retrospectively.

These hurdles might encourage one to think that Nietzsche's vitality criterion needs to be construed in maximally perspective-independent and neutral terms. This would give us a neutral standpoint from which to identify a set of values which, by that criterion, would be absolutely best. But this, quite apart from being dubious as a reading of Nietzsche, would certainly be a mistake in Williams' eyes. In ethics, Williams maintains, we should not try and determine which values are absolutely best according to some maximally abstract and perspective-neutral standard. ${ }^{16}$ This is not merely the trite point that we cannot do so, because we cannot entirely stand back from our values if we are to evaluate alternative values. That is also true - as Williams puts it, there is no Archimedean standpoint, and even if there were, it is a standpoint from which we could not decide the respective merits of values, because we would shed the evaluative resources to do so in striving for what George Eliot called 'that bird's eye reasonableness which soars to avoid preference and loses all sense of quality' (I999: 8I4). ${ }^{17}$

But the fact that one needs to evaluate from something would be allowed for as long as one had the vitality criterion as an evaluative basis. Williams' objection is not just that there is no Archimedean standpoint, but that the very urge to move towards such a standpoint, while legitimate in science, is out of place in ethics. Ethics is radically first personal in a way that science is

${ }^{16}$ Williams (I995c: I64-70; 2003; 2006b: I93-4).

${ }^{17}$ This is a central theme in Williams (20II: esp. ch. 2). 
not, and it is a misunderstanding of ethical evaluation to think that we should aim to be 'unencumbered intelligences selecting in principle among all possible outlooks' - it is a 'scientistic illusion' to think that it is 'our job as rational agents to search for, or at least move as best we can towards, a system of political and ethical ideas which would be the best from an absolute point of view, a point of view that was free of contingent historical perspective' (Williams 2006b: I93-4). Bringing my personal loyalties and attachments to bear on ethical evaluation is not necessarily a distortion to be avoided, because the evaluation is not just incidentally mine: 'my life, my action, is quite irreducibly mine, and to require that it is at best a derivative conclusion that it should be lived from the perspective that happens to be mine is an extraordinary misunderstanding' (Williams I995c: 170). Hence, the very ambition to rank values according to some perspective-neutral criterion that will tell us which are absolutely best is a scientistic misunderstanding of ethics. In ethics, the Archimedean urge must be resisted. ${ }^{18}$

For Williams, then, Nietzsche's question whether some other set of values will help us to live both cannot and should not function as a criterion. It cannot function as a criterion if it is construed in terms that render it sensitive to the content of the evaluative outlook under consideration, because that renders the only version of the criterion that is accessible to one irrelevant. And it should not function as a criterion if it is construed in content-neutral terms, because that would embody a scientistic misunderstanding of the ethical evaluation at stake. So either way, the question does not function as a criterion.

In addition to this main line of criticism, Williams also sees a number of other structural difficulties for the Nietzschean project which, while they do not in principle threaten the idea that one might choose values on the basis of the vitality criterion, nonetheless highlight some serious epistemic and practical hurdles. These are worth attending to also because they are revelatory of how Williams interpreted the project itself.

First, Nietzsche conceives of his project in overly individualistic terms on Williams' view. His 'models of overcoming and transforming our values, which is his most enduring concern', Williams points out, 'tend to be personal, individualistic, occasionally heroic' (2006d: 327 ). Often, the undertaking 'is regarded as an expression simply of a personal endeavour, like that of an artist; sometimes it takes on an historically transformative note, as though the individual's feat of transvaluation will itself change society' (2006d: 327). In opposition to this individualistic model, Williams insists that values come in socially shared webs which individuals, however heroic, would be powerless to change on their own. ${ }^{19}$ The project is also overly individualistic in a different

\footnotetext{
${ }^{18}$ The phrase 'Archimedean urge' hails from Srinivasan (2015).

${ }^{19}$ See Kusch (2009) and Queloz (2018; forthcoming-b: ch. 7) for further discussion of this aspect of Williams' conception of values.
} 
sense, moreover: there is something remarkably apolitical about considering the question of what values an individual should live by in order to flourish in isolation from the political order in which these values are expressed. That order will itself reflect political values, and the question of what personal values would help a given individual to live cannot be answered independently of the question of what political values a society should embody. But as Williams repeatedly emphasizes, Nietzsche betrays a severe lack of sensitivity to the political dimension of his concerns. ${ }^{20}$

Secondly, Nietzsche's conception of his project is too voluntaristic: we cannot simply choose to value something, for in order to succeed in valuing it, we need to be able to make sense of it as valuable, and what 'makes sense to someone is not, in any connection, a matter of will' but rather 'comes as a discovery' (Williams 2002: 26I-2). What determines whether something can make sense to us as valuable? Williams highlights two conditions. ${ }^{21}$ On the one hand, it must engage our ethical emotions, and whether it does so depends not on an act of will, but on one's education, socialization, and other processes by which one has cultivated a certain emotional sensibility. On the other hand, it must be conceptually articulated and intelligibly related to other things that we value, as instantiating, bearing, expressing, or facilitating them, so that there can be an answer to the question of what it is about something that one values. Merely understanding that adopting some value would help us in some respect does not yet suffice to internalize that value. In a Prisoner's Dilemma, for example, understanding that I have instrumental reason to come to treat the welfare of other players as intrinsically valuable provides no stable ground for me to do so: if all I have to support the value I am trying to reason myself into is the thought that $I$ have reason to treat it as a value, this will not be enough for me to make sense of it as a value, and my attempt to pretend otherwise will unravel upon reflection. ${ }^{22}$ It must be possible to say more about why something is valuable. As long as we remain unable to do so, the value remains humanly unintelligible. Isaiah Berlin offers a vivid illustration of this point:

If I find men who worship trees, not because they are symbols of fertility or because they are divine, with a mysterious life and powers of their own, or because this grove is sacred to Athena - but only because they are made of wood; and if when I ask them why they worship wood they say 'Because it is wood' and give no other answer; then I do not know what they mean. (I997: Io)

Williams' own example is the value of truthfulness: the Greeks made sense of truthfulness as a value by relating it to other things that they valued, such as honour and nobility of character; later societies have made sense of it

${ }^{20}$ See Williams (I999a: I50; 1999b: 257; 2006d: 326-7; 2012: I4I).

${ }^{21}$ See Williams (2002: 9I-2; 2006c: I35-7).

${ }^{22}$ This is how Williams attacks Gauthier's (1986) proposed solution to the Prisoner's Dilemma (Williams 2002: 9I). 
in different terms, by relating it instead to notions of freedom and absence of manipulation; but in each case, people could coherently make sense of truthfulness as a value because that value was fleshed out and supported by its connections to other things of value. ${ }^{23}$ When we discover that something makes sense to as a value, part of what we discover are these connections to other things that we value. But such connections cannot be forged by an effort of will. Hence, we cannot simply choose to value something.

Thirdly, new thoughts have to be generated out of the material made available to us by history. We 'do not make our thoughts out of nothing' (Williams 2006d: 327), and societies can no more transcend their historical conditions in this respect than individuals can transcend their social conditions. Part of Williams' point is that since nothing comes from nothing, innovation is subject to developmental constraints or path dependences: new valuations have to be forged out of the old ideas we have inherited by combining, elaborating, or extending them; moreover, taking up once more the idea that values have to make sense to us as values - merely recognizing the practical necessity of coming to see something as valuable does not suffice actually to do so-the conceptual material in terms of which we make sense of these better values will itself have to be drawn from our conceptual inheritance. But there is also an internalist rationale for highlighting the constraints imposed by our conceptual inheritance: for an internalist about reasons such as Williams, the very reasons for adopting new values will have to tie in with antecedent motivational states, the content of which will have to be articulated in terms of extant concepts. One's conceptual inheritance does not just impose limits on what values one can adopt, therefore, but also on what values one can find that one has reason to adopt.

Fourthly, Williams adds that the material out of which we develop values is in many respects obscure to us, because we only dimly and incompletely understand what the ideas we inherit entail, where they conflict with one another, and what historical deposits they carry with them. Our thoughts and ideas are the product 'of an obscure mixture of beliefs (many incompatible with one another), passions, interests, and so forth' (2005: I2-3), and when new thoughts and ideas form, these 'come in part from what is around us, and we have a very poor grasp, for the most part, of what their source may be' (2006d: 327). In addition to being limited in the values we can adopt or have reason to adopt, we are thus also epistemically limited in our understanding of where and what we draw these values from.

Finally, these epistemic limitations apply even more severely with regard to the future consequences of adopting possible values. We have difficulties anticipating what the effects of adopting a value will be, because too many of

${ }^{23}$ See Williams (I973a, I997: 26; 2002: 89-92, I15; 2006c: г36). 
the consequences of concept use are unintended by and opaque to concept users:

What ideas actually do is not under the control of their creators, and is rarely what their creators intend. Their ideas may help to shape other people's aims, but they are more deeply at the mercy of those other people's needs, and of opaque historical contingency. (Williams 2006d: 327)

We may think we have a firm grasp of the practical consequences of adopting a value. But a value that has beneficial consequences in one set of circumstances may have pernicious consequences in another set of circumstances; moreover, as the value comes to be adopted by an increasing variety of people, it will also be adapted to their needs and situations in ways that may alter both the value and its practical consequences. Once in circulation, a concept is open to appropriation, reinterpretation, and repurposing by others in ways that render its net effect on human lives extremely difficult to foretell. Nietzsche's own ideas of the will to power or the Übermensch - appropriated, distorted, and exploited by just the nationalistic and anti-Semitic movements he himself despised and deplored - are a case in point.

In the face of all these structural problems for the Nietzschean project, Williams concludes that there can be no question of making a criterial choice between the values we have and the values we might come to live by- 'there is no way in which, in these fundamental respects, the understanding of life can get ahead of life itself' (2006d: 328 ). All we can do is recognize whether or not the values we have help us to live, as measured by those same values. Whether that is the case will be immediately manifest in how we are managing to live, and, as Williams' pointer to genealogical explanation indicates, it will be manifest in retrospect in how we and others have managed to live in the past. But there is no room for a prospective criterial choice between values. ${ }^{24}$

\section{A MERE REVERSAL OF VALUATIONS}

Before we come to Nietzsche's defence, it is worth noting that many of the ideas that Williams deploys against the Nietzschean project are very much Nietzschean ideas. Most notably, there are several places where Nietzsche

${ }^{24}$ A reviewer points out that Williams' critique will seem to have less bite if one reads Nietzsche as advocating what is sometimes called moral 'experimentalism' (Bamford 20I6; Hunt i99I: ch. 7), which invites one to experiment with new values and evaluate them as one goes along. But either the choice of which values to move over to and experiment with is a rationally grounded choice, in which case even the experimentalist reading remains - at least where radical value experiments are concerned — vulnerable to Williams' point that the understanding of life cannot get ahead of life itself, or the choice is an initially arbitrary choice that then proves its worth in the course of the experience of living by those values, in which case the experimental reading ends up conceding Williams' point. 
proves mindful of the perspectival character of the criterion for whether something helps or hinders the attainment of the 'highest power and splendor of the human type' (I998: Preface, §6). He does not take himself to be in a position to say - indeed clearly wishes not to say - what this future human type should look like. The notion of the highest power and splendour of the human type functions as a placeholder: unlike Aristotle, Nietzsche does not believe in a constant and uniform human nature from which an absolute, one-size-fits-all notion of the 'full realization' of human nature could be derived. And unlike the Christian morality he opposes, he does not believe that there is a one-size-fits-all ideal of a human being which unites all definitively desirable properties. ${ }^{25}$ As he says, the point is precisely not 'to direct and edify, to maintain one's own type as the first and highest' (2009: I888, I4[225]). He condemns as a relic of the 'Christian prejudice' the 'optical habit' [optische Gewöhnung] of estimating the value of the human being according to how close it comes to some 'ideal human being' (2009: I887, I [ [226]): 'one thinks one knowes what, with regard to the ideal human being, is of definitive desirability' (2009: I887, II [226]). But 'any careful examination of this "ideal type" will lead one to abandon it immediately. It is the 'Christian ideal' that leads one to 'think one knows, first, that approximation to One single type is desirable; second, what this type is like; third, that any deviation from this type constitutes a decline, an inhibition, a loss of strength and power for mankind' (2009: I887, I [ [226]). These and other passages suggest that Nietzsche is keenly aware that the assessment of whether a set of values helps us to live depends on who and where we are.

Similarly, many of the other issues Williams raises arguably turn on Nietzschean ideas. The idea that the understanding of life cannot get ahead of life itself is sometimes attributed to Nietzsche under the heading of 'experimentalism'. ${ }^{26}$ That the sources and consequences of our thoughts are in many respects opaque to us is a leitmotif throughout Nietzsche's work, and his conception of a revaluation of values is less naïve than Williams' critique may lead one to think:

To revalue values - what would that mean? The spontaneous movements must all be there, the new, future, stronger ones: it is only that they still stand under false names and valuations and have not yet become conscious of themselves. (2009: 1887, 9[66])

Any doctrine is pointless if all the accumulation of forces and explosive materials it demands are not yet in place. A revaluation of values is achieved only when there is a tension from new needs, from the newly needy [Neu-Bedürfigen], who suffer from the old valuation without coming to consciousness [ohne zum Berwußtsein zu kommen] (2009: I887, 9[77]).

\footnotetext{
${ }^{25}$ See Leiter (2015) for a valuable discussion of this point.

${ }^{26}$ See Hunt (1991: ch. 7) and Bamford (2016).
} 
As these little-known passages bring out, Nietzsche does show some awareness of how the success of the project of revaluation depends on the necessary material and the necessary driving forces being available in society. He knows that individuals cannot transcend their social and historical conditions, that they do not create their thoughts ex nihilo, and that the understanding of life cannot get ahead of life itself.

In effect, Williams channels one current in Nietzsche's thought to drive back another, and as we saw at the beginning, Williams himself conceives of what he is doing in these terms: he presents the main point of his critique as 'one of Nietzsche's most important lessons' (2000: I6I); he prefaces his criticism of the idea that one might anticipate the effects that adopting a value will have with the claim that this idea 'belies one of [Nietzsche's] thoughts' (2006d: 327); he notes that the individualistic or artistic model of value creation 'is not true to much else that Nietzsche believed' (2006d: 327), and remarks that while Goethe's dictum, 'in the beginning was the deed', was not in fact cited by Nietzsche, it 'might well have been' (2006d: 328 ). In a conciliatory tone, Williams also emphasizes that Nietzsche was anyway keener on spelling out the character traits of creators of values than on spelling out the content of their values (2006d: 329), and he intriguingly suggests at one point that Nietzsche's individualism might be a feature of his mode of presentation rather than a substantial commitment about how the revaluation of values actually works, because 'a social process which in actual fact no doubt has many stages, discontinuities, and contingencies . . . can be illuminatingly represented on the model of a certain kind of psychological strategy' (2000: I58). Since Nietzsche anticipates much of the Williamsian critique, and since Williams himself is aware of that fact, the Williamsian critique can thus be seen as an internal critique of Nietzsche's thought.

Even conceived as an internal critique, however, the Williamsian critique seems to leave us at precisely the point in Nietzsche's intellectual development where Nietzsche had the means to make sense of a devaluation of values, but not of a revaluation of values: roughly, it vindicates the Nietzsche of Human, All Too Human against the more ambitious Nietzsche of Daybreak and later works. ${ }^{27}$

But perhaps we can come to the defence of Nietzsche's ambitions by specifying more carefully how ambitious the envisaged revaluation itself is supposed to be. Revealingly, Williams takes it to be quite ambitious: he writes that Nietzsche 'leaves us for the most part with an image of some solitary figure bringing new values into existence' (2006d: 327 ), and that although he 'rightly foresaw' that the false presuppositions of many of our present values 'would one day come to be generally recognized', he 'almost completely failed in his visionary attempts to grasp what could take their place' (ig84: 255).

${ }^{27}$ See Owen (2007: 20) and Ridley (2005). 
As we noted at the beginning, however, the German Umwerthung suggests a shift in or a reversal of values rather than the wholesale de novo creation of values, and, especially in the work that until the last minute was to be called The Revaluation of All Values (and which Nietzsche eventually retitled The Anti-Christ: $A$ Curse on Christianity), Nietzsche can give the impression that his chief concern is not to create new values ex nihilo, but to reverse the polarity of existing valuations in order thereby to undo the revaluation of values that brought us Christianity. ${ }^{28}$ He even singles out the Renaissance of Cesare Borgia as the time that came closest to completing just the revaluation of values that Nietzsche advocates: the replacement of Christian values by 'opposite values, noble values' (2005b: §6I). ${ }^{29}$ As David Owen (2018: 73-5) and others have argued, these values are humanistic values encouraging the continual setting and overcoming of ideals in this life rather than the next. Roughly, they are the values of Renaissance virtù, which Nietzsche liked to call 'moraline-free virtue' (2005b: §2; 2009: I887, Io[45, 50, I09], II [43, IIO, 4I4], I888, I5[20]).

Particularly in his late work, there are thus passages in which Nietzsche seems to understand 'revaluation' not as a bringing into existence of new values, but merely as an inversion of our present valuations aiming to bring back valuations that formerly existed. Of course, for each of these passages, there are countervailing passages where Nietzsche speaks of the need for 'law-givers' and 'creators' of new values while studiously avoiding to specify what these future values should look like (200г: $\S \S 30$ I, 335; 2002: $§ \S 2$ I , 253; 2005a: 'Fate', 44 ; 2006: Preface, §9; 2009: I884, 26[243], I886, 6[25], I887, I [ [4I I]). ${ }^{30}$ And even where he talks about the 'fear-inspiring consistency' with which the 'aristocratic value equation $($ good $=$ noble $=$ powerful $=$ beautiful $=$ happy $=$ beloved of God)' was inverted to suggest that the 'miserable', 'poor', 'powerless', 'suffering', and 'ugly' were beloved of God (I998: I, §7), it is clear that some values are exempt from this inversion: the rank order between truthfulness and lying, for example, is not inverted. ${ }^{31}$

But the point remains that at least insofar as revaluation issues only in new valuations rather than in new values, it merely requires changing the valence of existing concepts. The distinction between valuations and values therefore gives Nietzsche the means to resist Williams' critique. Insofar as the

\footnotetext{
${ }^{28}$ See, e.g., Stern (2018).

${ }^{29}$ Borgia was the son of the Pope, and had he not fallen ill, this ruthless operatorMachiavelli's model for the Machiavellian - might well have become Pope himself, something which Nietzsche thought would have spelled the end of Christianity. As Jacob Burckhardt already remarked, Borgia 'could have secularized the States of the Church, and he would have been forced to do so to keep them ... He, if anybody, could have ... annihilate[d] the Papacy' (I990: 88).

${ }^{30}$ On Nietzsche's ambition to create values, see Clark (2015a), Dries (2015), Langsam (2018), and Lambert (2019).

${ }^{31}$ For different attempts to explain why the rank order between truthfulness is not inverted, see Owen (2007: 70) and Queloz (forthcoming-a).
} 
idea is to revert back to valuations that have helped us to live in the past, revaluation can be guided by retrospective assessments of what kinds of lives values historically tended to foster. There will then be no need to evaluate values whose content we do not yet grasp and whose effects on society we cannot fathom. Nor will one need to create entirely new ways of thinking. One will only need to present the properties and character traits in terms of which we already think in a contrasting moral light. In that sense, the revaluation of values involves not value creation, but merely the old rhetorical strategy that Quintilian termed the paradiastolic redescription of virtues as vices and vices as virtues - a redescription, moreover, which by Nietzsche's lights is just the reversal of a previous redescription along these same lines. ${ }^{32}$ The title Der Anti-Christ, which in German can also mean The Anti-Christian, then appears well chosen: Nietzsche characterizes what he advocates negatively, as a mere reversal of Christian valuations.

\section{SAINT-JUST'S ILLUSION}

Even this mere reversal of existing valuations must seem suspicious to Williams, however, for its optimism that formerly helpful values can be safely revived and expected to work just as well for us, under our very different circumstances, is precisely what Williams attacked under the heading of 'Saint-Just's illusion'. ${ }^{33}$ Louis Antoine de Saint-Just, the French revolutionary who became Robespierre's right hand and is often seen as the purest embodiment of the Jacobin ideology (his angelic features and steely ruthlessness during the Reign of Terror earned him the sobriquet 'Angel of Death'), tried to recreate, in I8th-century France, an ideal of civic virtue drawn from Roman antiquity. 'Let Revolutionists be Romans' (2004: 820), he urged. 'The world has been empty since the Romans' (735). ${ }^{34}$

The illusion from which Saint-Just suffered according to Williams was the illusion of thinking that the values of ancient Rome were a live option for revolutionary Paris - that these values could simply be transplanted from antiquity into a world with completely different needs and social and economic structures. The particular way in which a value such as freedom was expressed and concretely elaborated in ancient Rome may have answered to the needs of Roman society. But as Williams points out, a value 'can demand different social and political expressions at different times', and what makes a value

\footnotetext{
32 The connection to paradiastolic redescription is also drawn by Skinner (2002: I85), Owen (2018), and Srinivasan (2019: I44).

${ }^{33}$ See Williams (1995b). He takes the phrase from Marx and Engels' The Holy Family.

${ }^{34}$ See Linton (2010) and Andrew (201r: chs 6 and 7) for accounts of how Saint-Just selfconsciously modelled himself and his ideals on those of the Roman republic. In this he was but an extreme example of a general tendency among the revolutionaries.
} 
'viable in one set of historical conditions may make it a disaster in another: that was the nature of Saint-Just's illusion' (1995d: I37). Blind to the way in which the viability of particular expressions of values is a function of the sociohistorical context in which they are put to work, Saint-Just tried to impose ideas on modern French society that were entirely alien to it and could never have worked in it.

Now Nietzsche, in calling for a reversal of the Christian revaluation, likewise lays himself open to the charge of succumbing to Saint-Just's illusion. There is every reason to fear that what made virtù a viable alternative to Christian virtue in the Italian Renaissance will make it a disaster under conditions of modernity - and Nietzsche's enthusiastic pointer to Cesare Borgia is hardly reassuring.

By interpreting Nietzsche's project so that it can sidestep some of the problems we highlighted above, then, we just render the project vulnerable to the objection that the inference from the success of an older set of values in their particular sociohistorical circumstances to the idea that they will similarly succeed under modern-day conditions is both a lapse of historical sense and a dangerous ethical and political error.

Yet it turns out that Nietzsche appears to have been aware of that difficulty as well. In The Gay Science, he speaks to this very issue and even employs the same example:

The French of Corneille's age as well as those of the Revolution seized Roman antiquity in a way we no longer dare to - thanks to our higher historical sense. And Roman antiquity itself: how violently and yet naively it laid its hand on everything good and lofty in the older Greek antiquity! How they translated things into the Roman present! ... They seem to ask us: 'Should we not make new for ourselves what is old and put ourselves into it? Should we not be allowed to breathe our soul into their dead body? For it is dead, after all: how ugly everything dead is!' They did not know the pleasure of a sense for history. (2001: $\S 83$ )

Nietzsche uses the phrase 'historical sense' in a variety of ways, but the relevant sense here seems to be exactly the one at stake in Saint-Just's illusion: one betrays a lack of historical sense if one fails to grasp how past values were embedded in, and drew their point from, an entire form of life. As Nietzsche writes in Human, All Too Human, the historical sense consists in the ability to rapidly 'conjure up a certain horizon' or 'system of ideas and sensations', just as one conjures up 'the impression of a temple on the basis of a few pillars and pieces of wall that chance to remain standing' (I986: I, §274). In Beyond Good and Evil, historical sense is characterized as the ability 'quickly to guess the rank order of the valuations that a people, a society, an individual has lived by' as well as the 'connections between these valuations' (2002: §224). The draft of this passage in his notebook revealingly adds: 'the relation of these valuations to the conditions of life, the relationship between the authority of values and 
the authority of effective forces (the presumed relationship usually even more than the actual one): the ability to reproduce all this in oneself is what constitutes historical sense' (2009: I885, 35[2]). In Nietzsche's view, one displays historical sense notably by grasping the connection between valuations and the form of life in which they are embedded.

If one assumes that Nietzsche the philologist was too historical a thinker to fall for Saint-Just's illusion - if one assumes, in particular, that he was aware of how the viability of particular expressions of values depends on the context in which they are deployed - then the insight animating the charge of Saint-Just's illusion might be turned into a steppingstone by which to overcome it. The tel quel transplantation of Renaissance conceptions into modern society may founder on the fact that viable values demand new expressions and elaborations in different sociohistorical contexts; but this just shows that what is needed are new expressions and elaborations of the values underlying Renaissance conceptions - expressions and elaborations adapted to the modern context. What we should aim to recreate, therefore, is not the Renaissance conception of virtue itself, but the benefits and possibilities it brought in its wake. The guiding question will then be: What new elaborations and expressions of values do new contexts demand in order to deliver the same goods as past elaborations and expressions of those values in past contexts?

There is some textual evidence to suggest that Nietzsche indeed understood that values would require different expressions and elaborations in different contexts. For example, he suggests at one point that the contest of valuations that concerns him unfolds throughout Western history, with two sets of valuations re-emerging again and again in notably different guises (I998: I, $\S 16)$.

The crunch, however, is that even if Nietzsche is aware of the pitfalls involved in Saint-Just's illusion, this awareness can only drive him back to the idea that what we need are values that, at least in their expression, elaboration, and concretization, are not the recycled values of a bygone era, but values which are adapted to our own, novel circumstances; and to the extent that they are that, they will be precisely what we were trying to avoid, namely genuinely new values whose anticipation and assessment must once again give rise to the difficulties we started out from. The line of interpretation leading past Saint-Just's illusion thus runs into just the host of problems that the line of interpretation leading to Saint-Just's illusion was intended to get away from in the first place.

On either interpretation of the revaluation of values as a project, then, the Williamsian critique highlights serious difficulties for it, difficulties which are neither specific to Nietzsche nor to the substance of his criterion. Perhaps further reflection on these matters can show that some of these difficulties can be overcome. But what the present discussion suggests is that they really do need to be overcome, and the value of flagging these difficulties lies in the guidance it 
offers in that regard, not only to those seeking an interpretation of Nietzsche's project on which it emerges as viable, but also - since the difficulties have not gone away - to those in conceptual ethics and conceptual engineering who seek to continue what he began. ${ }^{35}$

\section{REFERENGES}

Andrew, E. (201 I) Imperial Republics: Revolution, War and Territorial Expansion from the English Civil War to the French Revolution. Toronto: University of Toronto Press.

Bamford, R. (2016) 'The Ethos of Inquiry: Nietzsche on Experience, Naturalism, and Experimentalism', Fournal of Nietzsche Studies, 47: 9-29.

Berlin, I. (1997) The Proper Study of Mankind. London: Chatto and Windus.

Burckhardt, J. (1990) The Civilization of the Renaissance in Italy. London: Penguin.

Burgess, A., Cappelen, H. and Plunkett, D. (eds) (2020) Conceptual Engineering and Conceptual Ethics. Oxford: OUP.

Callard, A. (2018) Aspiration: The Agency of Becoming. New York: OUP.

Cappelen, H. (2018) Fixing Language: An Essay on Conceptual Engineering. Oxford: OUP.

Cappelen, H. and Plunkett, D. (2020) 'Introduction: A Guided Tour of Conceptual Engineering and Conceptual Ethics', in A. Burgess, H. Cappelen and D. Plunkett (eds) Conceptual Engineering and Conceptual Ethics, I-26. Oxford: OUP.

Clark, M. (2015a) 'On Creating Values', Nietzsche-Studien, 44: 98-103.

(2015b) 'On the Rejection of Morality: Bernard Williams's Debt to Nietzsche', Nietzsche on Ethics and Politics, $4 \mathrm{I}-6 \mathrm{r}$. Oxford: OUP.

Dries, M. (2015) 'I.3 How Hard is it to Create Values?', Nietzsche-Studien, 44: 30-43.

Eklund, M. (2017) Choosing Normative Concepts. Oxford: OUP.

Eliot, G. (r999) Daniel Deronda. London: Everyman.

Gauthier, D. (1986) Morals by Agreement. Oxford: OUP.

Gemes, K. (2013) 'Life's Perspectives', in K. Gemes and J. Richardson (eds) The Oxford Handbook of Nietzsche, 553-75. Oxford: OUP.

Gemes, K. and May, S. (eds) (2009) Nietzsche on Freedom and Autonomy. Oxford: OUP.

Guay, R. (2006) 'The Philosophical Function of Genealogy', in K. A. Pearson (ed.) A Companion to Nietzsche, 353-70. Oxford: Blackwell.

Huddleston, A. (2015) 'What is Enshrined in Morality? Understanding the Grounds for Nietzsche's Critique', Inquiry, 58: 28I-307. (2019) Nietzsche on the Decadence and Flourishing of Culture. Oxford: OUP.

Hunt, L. H. (I99I) Nietzsche and the Origin of Virtue. London: Routledge.

Katsafanas, P. (2013a) Agency and the Foundations of Ethics: Nietzschean Constitutivism. Oxford: OUP.

- (2013b) 'Nietzsche's Philosophical Psychology', in J. Richardson and K. Gemes (eds) The Oxford Handbook of Nietzsche, 727-55. Oxford: OUP.

(2016) 'Naturalism, Minimalism, and the Scope of Nietzsche's Philosophical Psychology', in K. Gjesdal (ed.) Debates in Nineteenth-Century European Philosophy: Essential Readings and Contemporary Responses, 326-38. New York: Routledge.

Kusch, M. (2009) 'Testimony and the Value of Knowledge', in A. Haddock, A. Millar and D. Pritchard (eds) Epistemic Value, 6o-94. Oxford: OUP.

Lambert, T. (2019) 'Nietzsche on Greating and Discovering Values', Inquiry, 62: 49-69.

Langsam, H. (2018) 'Nietzsche and Value Creation: Subjectivism, Self-Expression, and Strength', Inquiry, 6r: 100-13.

${ }^{35}$ I am grateful to Damian Cueni, Amia Srinivasan, Johannes Steizinger, Rebekka Hufendiek, Jelscha Schmid, Markus Wild, David Owen, Friedemann Bieber, Alexander Prescott-Couch, and Manuel Dries for valuable discussions of these issues. I am also indebted to two anonymous reviewers for their thoughtful comments. 
Leiter, B. (2015) Nietzsche on Morality, 2 edn. London: Routledge.

(manuscript) 'Williams's Debt to Nietzsche: Real or Illusory?'.

Linton, M. (2010) 'The Man of Virtue: The Role of Antiquity in the Political Trajectory of L. A. Saint-Just', French History, 24: 393-4I9.

May, S. (1999) Nietzsche's Ethics and his War on 'Morality'. Oxford: OUP.

Merrick, A. (2018) 'We Need a Critique of Moral Values: Regarding On the Genealogy of Morality and Normativity', in P. Katsafanas (ed.) The Nietzschean Mind, 70-82. London: Routledge.

Moore, A.W. (2006) 'Maxims and Thick Ethical Concepts', Ratio, I9, I29-47.

Nietzsche, F. (1967) The Will To Power. New York: Vintage Books. - (1986) Human, All Too Human. Cambridge: CUP.

_ (1998) On the Genealogy of Morality. Indianapolis: Hackett.

- (2001) The Gay Science. Cambridge: CUP.

(2002) Beyond Good and Evil. Cambridge: CUP.

- (2005a) Ecce Homo. Cambridge: GUP.

(2005b) The Anti-Christ. Cambridge: CUP.

(2006) Thus Spoke Zarathustra. Cambridge: CUP.

(2009) Digital Critical Edition of the Complete Works and Letters. Edited by Paolo DIorio. Based on the critical text by G. Golli and M. Montinari. Berlin: De Gruyter. www.nietzschesource.org/eKGWB/.

Owen, D. (2007) Nietzsche's Genealogy of Morality. Stocksfield: Acumen.

(2018) 'Nietzsche's Antichristian Ethics: Renaissance Virtù and the Project of Reevaluation', in D. Conway (ed.) Nietzsche and The Antichrist: Religion, Politics, and Culture in Late Modernity, 67-88. London: Bloomsbury Academic.

Parfit, D. (1984) Reasons and Persons. Oxford: Clarendon Press.

Paul, L. A. (20I4) Transformative Experience. Oxford: OUP.

Prescott-Couch, A. (2014) 'Williams and Nietzsche on the Significance of History for Moral Philosophy', Journal of Nietzsche Studies, 45: 147-68.

Queloz, M. (2017), 'Nietzsche's Pragmatic Genealogy of Justice', British Fournal for the History of Philosophy, 25: 727-49.

- (2018) 'Williams's Pragmatic Genealogy and Self-Effacing Functionality', Philosophers' Imprint, I8: I-20.

_ (forthcoming-a) 'Nietzsche's English Genealogy of Truthfulness', Archiv fir Geschichte der Philosophie.

(forthcoming-b) The Practical Origins of Ideas: Genealogy as Conceptual Reverse-Engineering. Oxford: OUP.

Queloz, M. and Cueni, D. (2019) 'Nietzsche as a Critic of Genealogical Debunking: Making Room for Naturalism Without Subversion', The Monist, I02: 277-97.

Reginster, B. (2006) The Affirmation of Life: Nietzsche on Overcoming Nihilism. Cambridge, MA: Harvard University Press. Routledge.

Richardson, J. (2004) Nietzsche's New Darwinism. New York: OUP.

(2013) 'Nietzsche on Life's Ends', in J. Richardson and K. Gemes (eds) The Oxford Handbook of Nietzsche, 756-84. Oxford: OUP.

Ridley, A. (2005) 'Nietzsche and the Re-Evaluation of Values', Proceedings of the Aristotelian Society, I05: $155-75$.

Robertson, S. and Owen, D. (2013) 'Influence on Analytic Philosophy', The Oxford Handbook of Nietzsche, I85-208. Oxford: OUP.

Saint-Just, L.A. (2004) Les Euvres Complètes de Louis-Antoine de Saint-Just. Paris: Gallimard.

Skinner, Q. (2002) Visions of Politics I. Regarding Method. Cambridge: CUP.

Srinivasan, A. (2015) 'The Archimedean Urge', Philosophical Perspectives, 29: 325-62.

- (2019) 'Genealogy, Epistemology and Worldmaking', Proceedings of the Aristotelian Society, II9: $127-56$.

Stern, T. (2018) 'History, Nature, and the 'Genetic Fallacy' in The Antichrist's Revaluation of Values', in D. Conway (ed.) Nietzsche and The Antichrist: Religion, Politics, and Culture in Late Modernity, 2I-4I. London: Bloomsbury Academic. 
Ullmann-Margalit, E. (2006) 'Big Decisions: Opting, Converting, Drifting', Royal Institute of Philosophy Supplements, 58: 157-72.

Williams, B. (I973a) 'Morality and the Emotions', Problems of the Self, 207-29. Cambridge: CUP.

- (1973b) 'The Makropulos Case: Reflections on the Tedium of Immortality', Problems of the Self, 82-Ioo. Cambridge: CUP.

(I98I) 'Persons, Character, and Morality', Moral Luck, I-I9. Cambridge: CUP.

(I984) 'Präsuppositionen der Moralität', in E. Schaper and W. Vossenkuhl (eds)

Bedingungen der Möglichkeit: "Transcendental Arguments" und Transzendentales Denken, 251-61.

Stuttgart: Klett-Cotta.

(I986) 'Reply to Simon Blackburn', Philosophical Books, 27: 203-8.

- (r995a) 'Replies', in J. E. J. Altham and R. Harrison (eds) World, Mind, and Ethics: Essays

on the Ethical Philosophy of Bernard Williams, 185-224. Cambridge: CUP.

_ (1995b) 'Saint-Just's Illusion', Making Sense of Humanity and Other Philosophical Papers, $1982-$

1993, I35-50. Cambridge: CUP.

(I995c) 'The Point of View of the Universe: Sidgwick and the Ambitions of Ethics',

Making Sense of Humanity and Other Philosophical Papers, 1982-1993, I53-71. Cambridge: CUP.

- (I995d) 'Truth in Ethics', Ratio, 8: 227-36.

(I995e) 'What Does Intuitionism Imply?', Making Sense of Humanity and Other Philosophical

Papers, 1982-1993, I82-91. Cambridge: CUP.

(I996) 'Contemporary Philosophy: A Second Look', in N. Bunnin and E. P. Tsui-James

(eds) The Blackwell Companion to Philosophy, 23-35. Oxford: Blackwell.

- (1997) Der Wert der Wahrheit. Wien: Passagen.

- (r999a) 'Bernard Williams', in A. Pyle (ed.) Key Philosophers in Conversation: The Cogito

Interviewes, I42-63. London: Routledge.

- (1999b) 'Seminar with Bernard Williams', Ethical Perspectives, 6: 243-65.

(2000) 'Naturalism and Genealogy', in E. Harcourt (ed.) Morality, Reflection, and Ideology,

I48-6I. Oxford: OUP.

(2002) Truth and Truthfulness: An Essay in Genealogy. Princeton: Princeton University Press. (2003) 'Relativism, History, and the Existence of Values', in R. J. Wallace (ed.) The Practice

of Value, I06-17. Oxford: Clarendon Press.

(2005) 'Realism and Moralism in Political Theory', in G. Hawthorne (ed.) In the Beginning

Was the Deed: Realism and Moralism in Political Argument, I-I7. Princeton: Princeton University Press.

- (2006a) 'Philosophy and the Understanding of Ignorance', in A. W. Moore (ed.), Philosophy as a Humanistic Discipline, I69-79. Princeton: Princeton University Press.

(2006b) 'Philosophy as a Humanistic Discipline', in A.W. Moore (ed.) Philosophy as a Humanistic Discipline, I80-99. Princeton: Princeton University Press.

- (2006c) 'Plato's Construction of Intrinsic Goodness', in M. Burnyeat (ed.) The Sense of the

Past: Essays in the History of Philosophy, I18-39. Princeton: Princeton University Press.

_ (2006d) 'There Are Many Kinds of Eyes', in M. Burnyeat (ed.) The Sense of the Past: Essays in the History of Philosophy, 325-30. Princeton: Princeton University Press.

- (2006e) 'Understanding Homer: Literature, History and Ideal Anthropology', in M.

Burnyeat (ed.) The Sense of the Past: Essays in the History of Philosophy, 6o-7o. Princeton: Princeton

University Press.

- (201 I) Ethics and the Limits of Philosophy. London: Routledge.

(2012) 'Nietzsche: The Gay Science', in R. B. Pippin (ed.) Introductions to Nietzsche, I37-5I.

New York: CUP.

Wolfson College, University of Oxford, UK 